\title{
A Survey on Building Safety After Completing The Construction Process in Malaysia Using Statistical Approach
}

\author{
Nurnadiah Zamri", Fadhilah Ahmad ${ }^{\#}$, Amira Husni Talib", Mohamad Shafiq Mohd Ibrahim ${ }^{\text {\& }}$ \\ ${ }^{\#}$ Faculty of Informatics and Computing, Universiti Sultan Zainal Abidin, Tembila, Besut, Terengganu, Malaysia \\ E-mail: adiahzamri@unisza.edu.my,fad@unisza.edu.my \\ *Department of Mathematics, Faculty of Science and Technology, Universiti Malaysia Terengganu, Terengganu, Malaysia \\ E-mail: amirahusnitalib@gmail.com \\ ${ }^{\circledR}$ School of Dental Sciences, Health, Universiti Sains Malaysia, Kubang Kerian, Kelantan, Malaysia \\ E-mail: shafiqmat786@gmail.com
}

\begin{abstract}
Building condition is an important issue in all over the world to enhance safety, health and sustainability of built environment. The objective of this study is to determine the most frequent causes of building failures in order to avoid the building from collapses, cracks and so on. The collection of data has been done among the engineers, workers and public. The questionnaire was distributed among engineers, contractors and public with 100 respondents. This survey focuses on two main parts of the safety which are building design and building management. The building designs are divided into four main criteria which are building structure, service design, building fitting and hazard environment. Meanwhile, the item of building management is focused on the management criteria. Results are analysed using statistical approach. Structural equation modeling (SEM) is used to evaluate the efficiency of the models' fitness and goodness. The survey shows that all criteria are importantly needed in maintaining the safety of building after completing the contraction process.
\end{abstract}

Keywords — building design; building management; structural equation modelling (SEM)

\section{INTRODUCTION}

Building condition is an important issue in all over the world to enhance safety, health and sustainability of built environment. In construction industry, the case of building collapse after completing the construction process happens although the building has been received the Certificate of Fitness for Occupation (CFO). The building design and building management contribute to the building failures. There are building designs that neglect external disasters such as typhoon, earthquake, flood and fire. In [1] defined the structural failure as the reduction of the capability of a structural system or component to such a degree that it cannot safely serve its intended purpose. In [2] discovered 225 cases of building failures that occurred on 1989 to 2000 .

The earthquake that struck the Canterbury region of New Zealand on February 22nd, 2011 requires all new buildings in New Zealand are able to withstand a moderate earthquake. The buildings such as hospitals and police stations need to be able to withstand a higher level of shaking than a building with only a few occupants and less requirement for business [3]. The fire safety engineering design of concrete structures in Indonesia is principally based on the individual member from results of isolated beams, columns and slabs tested in small furnaces. However, researchers identify that the behaviour of individual isolated members is significantly different from the behaviour of the complete structure connected together when subjected to fire [4].

Extreme winds may cause damage to low-rise buildings in the form of windows damage, roof loss or even complete collapse of wooden structures. In tall buildings, both cladding loads and the dynamics of the structure become a concern. The uses of high strength, lightweight materials, longer floor spans and more flexible framing systems result in structures that are more prone to vibrations [5]. In [6] studied that many building defect complaints are reported in public buildings such as ceiling collapse in Parliament building in the year 2006, leaking pipes in Official Court Jalan Duta, Kuala Lumpur and fungal appearance at the Sultanah Aminah Hospital Johor in Year 2007.

Highland Tower, an apartment building, collapsed in Selangor, where about 48 people dead. Roof collapse at Sultan Mizan Zainal Abidin Stadium on 2nd June 2009, a year after officially opened to host the SUKMA Games. 
Structural failure is the major causes of building collapses and followed by faulty design, poor workmanship, substandard materials, building usage, illegal conversion, inexperienced contractor and surrounding building [7]. In [8] reported that building collapse occurs due to the failure of design and management. The building design refers to the structure, service, and fitting while building management refers to the evacuation plan, safety education and security management.

Structural equation modeling (SEM) is used to evaluate the goodness of fit of the model. Several measures is being used such as Chi-square/degree of freedom (CMIN), Goodness of fit index (GFI), Normalized fit index (NFI), Incremental fix index (IFI), Tucker-Lewis index (TFI), Comparative fit index (CFI), Akaike information criterion (AIC) and Root mean square error of approximation (RMSEA). CMIN is the ratio of Chi-square statistics and degree of freedom. The value of CMIN 3 or less than is assumed to be a good fit with observed data [9]. The values of GFI, NFI, IFI, TLI and CFI was ranging from 0 to 1 , the value GFI, NFI, IFI and TLI greater than 0.90 and value greater than 0.95 for CFI indicated as a good fit [10-13]. The range value for RMSEA indicated as the value 0 interpreted as an exact fit, values less than 0.05 are close fit where value between 0.05-0.08 are a fair fit, values between 0.08 and 0.10 are mediocre fit and the values more than 0.10 are presented as a poor fit [11]. The AIC value indicates that the smaller value, the better the model for the comparison of the model [12].

Therefore, the survey on safety of the building is carried out through this study. The collection of data has been done among the engineers, workers, and public. The objective of this study is to determine the most frequent causes of building failures in order to avoid the building from collapses. This paper consists of four sections; introduction, research method, results and discussion, and conclusion.

\section{MATERIAL AND METHOD}

The collection of data has been done among the engineers, workers, and public. The questionnaire was distributed based Table 1 and Table 2 among engineers, contractors and public with 100 respondents. The study focused on two parts which are building design and building management (refer Table 1 and Table 2).

Table 1 and Table 2 are summarized in Fig. 1, where the variables in this figure are divided into two parts unobserved and endogenous variables. Unobserved variables include four subcriteria which are structure, building fitting, management, and weather. The rest of the subcriteria are the endogenous variable which are beam, roof, slabs, drainage, ladder, electricity supply, lighting, ventilation, plumbing and sanitary services, fire services, lifts, emergency door, foyers area, water fountain, utility area, emergency generator, flood, earthquake, fire, typhoon, security management, emergency evacuation plan, documentation and evaluation, safety education, security management, occupant safety management and waste and cleaning services.

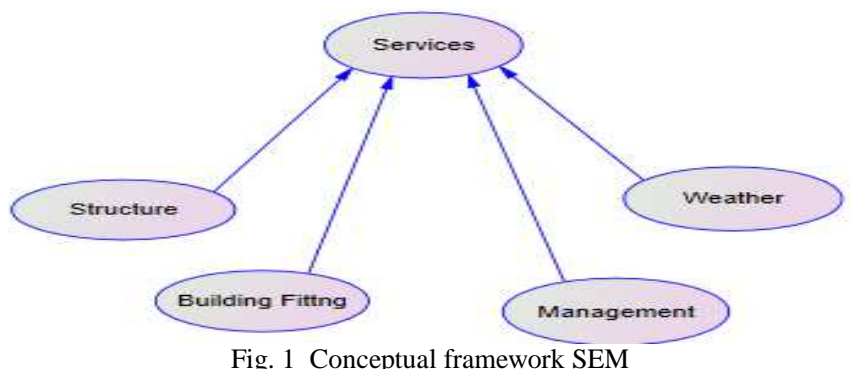

Fig. 1 Conceptual framework SEM

TABLE I

CRITERIA ON BUILDING DESIGN

\begin{tabular}{|c|c|c|c|}
\hline Item & Criteria & Subcriteria & Sources \\
\hline \multirow{11}{*}{ 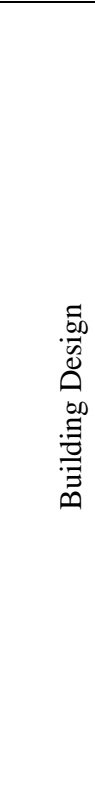 } & \multirow{5}{*}{ 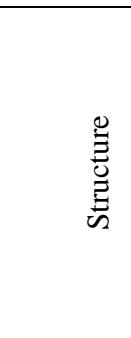 } & Beam [3] & The beam is the main structure in determining the safeness of building. \\
\hline & & Roof $[5,7]$ & $\begin{array}{l}\text { Roof not being properly erected resulted into misalignment, no quality control } \\
\text { on site, materials, and workmanship were not in accordance with specifications } \\
\text { and led to the collapse of the building. }\end{array}$ \\
\hline & & Slabs [14] & The structure of slab important to avoid an accident at the work places. \\
\hline & & Drainage [14-15] & $\begin{array}{l}\text { The bathroom floor drains were believed to be a contributing factor to the } \\
\text { outbreak of the building. }\end{array}$ \\
\hline & & Ladder [15] & $\begin{array}{l}\text { The structure of ladder is important to avoid the condition become worse in an } \\
\text { emergency situation. }\end{array}$ \\
\hline & \multirow{6}{*}{ 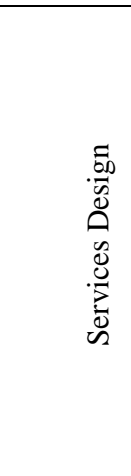 } & $\begin{array}{l}\text { Electricity Supply [8, } \\
14-15]\end{array}$ & Electricity supply can be the main factor of fire of the building. \\
\hline & & Lighting $[8,16]$ & Lighting fittings in buildings can prevent the occurrence of accidents. \\
\hline & & Ventilation $[8]$ & $\begin{array}{l}\text { The right ventilation and building care can prevent and fix indoor air quality } \\
\text { problems. }\end{array}$ \\
\hline & & $\begin{array}{l}\text { Plumbing and } \\
\text { Sanitary Services [8] }\end{array}$ & $\begin{array}{l}\text { The plumbing and sanitary services are a key position to influence the water } \\
\text { efficiency, sustainable site, energy, fire protection and pollution systems of a } \\
\text { facility. }\end{array}$ \\
\hline & & $\begin{array}{l}\text { Fire Services }[15,17- \\
19]\end{array}$ & $\begin{array}{l}\text { Provision of fire service in every building should be equipped with all of the fire } \\
\text { extinguishers and escape plan. }\end{array}$ \\
\hline & & Lifts $[14,15]$ & $\begin{array}{l}\text { Since malfunctioning of lifts and escalators can lead to disastrous consequences, } \\
\text { owners are bound by law to ensure lifts and escalators are in proper working } \\
\text { order whenever they are in use. }\end{array}$ \\
\hline
\end{tabular}


TABLE III

CRITERIA ON BUILDING DESIGN AND BUILDING MANAGEMENT

\begin{tabular}{|c|c|c|c|}
\hline Item & Criteria & Subcriteria & Sources \\
\hline \multirow{9}{*}{ 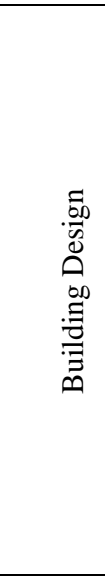 } & \multirow{5}{*}{ 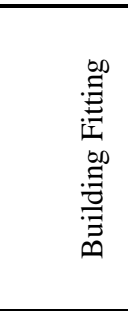 } & $\begin{array}{l}\text { Emergency Door }[4, \\
\text { 17] }\end{array}$ & Emergency door important to escape from fire. \\
\hline & & Foyers Area [17] & Foyers area is required for gathering in the emergency case. \\
\hline & & Water Fountain [15] & All the section of the building must be prepared the water fountain. \\
\hline & & Utility Area [14] & $\begin{array}{l}\text { The utility room has several uses but typically functions as an area to do } \\
\text { laundry. The room is also used for closet organization and storage. }\end{array}$ \\
\hline & & $\begin{array}{l}\text { Emergency } \\
\text { Generator }[15,17]\end{array}$ & $\begin{array}{l}\text { An emergency generator is needed especially when the electricity supply breaks } \\
\text { off. }\end{array}$ \\
\hline & 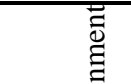 & Flood [2] & $\begin{array}{l}\text { External events such as rain, wind, snow and maintenance deficiencies have } \\
\text { been identified as the most frequent to building collapse. }\end{array}$ \\
\hline & .0 & Earthquake $[3,20]$ & The structure of building must be able to withstand of shaking. \\
\hline & 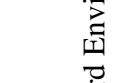 & Fire $[4,19]$ & $\begin{array}{l}\text { The building should be completed with an emergency plan and at high safety } \\
\text { level. }\end{array}$ \\
\hline & 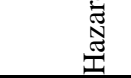 & Typhoon $[2,5]$ & $\begin{array}{l}\text { External events such as rain, wind, snow and maintenance deficiencies have } \\
\text { been identified as the most frequent to building collapse. }\end{array}$ \\
\hline & & $\begin{array}{l}\text { Security } \\
\text { Management [8] } \\
\end{array}$ & The management of building should be provided the security. \\
\hline$\vec{\Xi}$ & & $\begin{array}{l}\text { Emergency } \\
\text { Evacuation Plan [8, } \\
19]\end{array}$ & All the buildings must be prepared with the emergency evacuation plan. \\
\hline 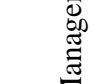 & 苞 & $\begin{array}{l}\text { Documentation and } \\
\text { Evaluation }[8,15]\end{array}$ & The safety of building should be evaluated before using the building. \\
\hline$\sum_{\substack{\infty \\
:=}}$ & $\sum_{\substack{\pi \\
\Xi}}^{\infty}$ & $\begin{array}{l}\text { Safety Education }[8, \\
21]\end{array}$ & The public should know the safety education. \\
\hline 常 & & $\begin{array}{l}\text { Occupant Safety } \\
\text { Management }[8,19]\end{array}$ & $\begin{array}{l}\text { Protecting the health, safety, and welfare of building occupants has expanded } \\
\text { beyond disease prevention and nuisance control to include mental as well as } \\
\text { physical health and protecting the ecological health of a place. }\end{array}$ \\
\hline & & $\begin{array}{l}\text { Waste and Cleaning } \\
\text { Services }[8,15]\end{array}$ & Cleaning and waste services as part of its facilities management solutions \\
\hline
\end{tabular}

Based on all subcriteria, the correlation analysis [24] is used to identify the relationships between all the subcriteria. Next, the structural equation modeling (SEM) is used to identify all the significant factors of the subcriteria. After that, this study used the Chi-square/degree of freedom (CMIN) where the value of CMIN is 3 or less than assumed to be a good fit with the observed data [9]. Next Goodness of fit index (GFI), Normalized fit index (NFI), Incremental fix index (IFI), Tucker-Lewis index (TFI), Comparative fit index (CFI) where the values of GFI, NFI, IFI, TLI and CFI was ranging from 0 to 1 , the value GFI, NFI, IFI and TLI greater than 0.90 and value greater than 0.95 for CFI indicated as a good fit [10-13]. Besides, it also used the Akaike information criterion (AIC) and Root mean square error of approximation (RMSEA). The range value for RMSEA indicated as the value 0 interpreted as an exact fit, values less than 0.05 are a close fit, where value between 0.05-0.08 are a fair fit, values between 0.08 and 0.10 are mediocre fit and the values more than 0.10 are presented as a poor fit [11]. The AIC value indicates that the smaller value, the better the model for the comparison of the model [12]. All the computations and results are explained in the next section.

\section{RESULTS AND DISCUSSION}
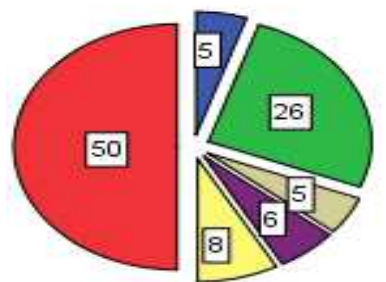

Architecture Civil Engineering $\square$ Mechanical Engineeering Electrical Engineering Surveying Others

Fig. 2 Respondent academic background

The collection of data has been done among the architecture, civil engineering, mechanical engineering, electrical engineering, surveying and others as workers and public. The questionnaire was distributed to 100 respondents which can be seen in Fig. 2. Most of the respondent were male which is 73 and followed by female which only 27 . The respondent age group which had the largest respondents was the group of 25-35 years old which was 50. Category age of 36-45 years old were 31. Category age of 46-55 years old were 13. And the least category age among the respondent was the group of below 25 years old which were 
only 6. Most of the respondent were government officials which consist of 56 out of 100 and followed by private 17 and others by 27 . It is also shown that most of the respondent length of service were less than 5 years and 10-14 years which are 34 out of 100 and followed by 5-9 years and 15 years above were 16 .

The building safety is one of the most important parts before it is safe to be occupied. The questionnaire consists of two parts which refer to the building design and building management. The percentage of each item of building safeness after completing the construction process was showed in the next section. The building design consists of four main questions which are structure, services design, building fitting and structure of the building by hazard environment. The structure consists of five main subcriteria which are beam, roof, slabs, drainage and ladder. Whereas, the service design consist of six subcriteria which are electricity supply, lighting, ventilation, plumbing and sanitary services, fire services and lifts. Moreover, the building fitting consists of emergency doors, foyers area, water fountain, utility area and emergency generator. The structure of building in considering the hazard environment was consisting of flood, earthquake, fire and typhoon. Whereas, the building management consist management approaches in considering the safeness after completing the construction process. The building management consists of six subcriteria which are security management, emergency evacuation plan, documentation and evaluation, safety education, occupant safety management and waste and cleaning services. The reliability statistic shows that the value of Cronbach's alpha is 0.908 as in Table 3. As the value were closer to 1 , the more reliable the scale of our variable [22].

TABLE IIIII

RELIABILITY STATISTICS

\begin{tabular}{|l|l|}
\hline Cronbach's Alpha & N of Subcriteria \\
\hline 0.908 & 26 \\
\hline
\end{tabular}

\section{A. Structure}

Fig. 3 until Fig. 7 show the results of distributed questionnaires for building safeness on the structure. Details on full explanations are discussed as follows;

Fig. 3 shows the percentage of building safeness for beam after completing the construction process. As can be seen, 30 respondents agreed that $100 \%$ is needed to complete the beam for the building safeness. Whereas 28 respondents agreed that $90 \%$ complete, 17 respondents agreed $80 \%$ complete, 16 respondents agreed $70 \%$ complete, 8 respondents agreed $60 \%$ complete, and only 1 respondent agreed $50 \%$ or less need to be completed.

Fig. 4 shows the roof percentage of building safeness after completing the construction process. As can be seen, 33 respondents said $90 \%$ need to complete the roof of the building to be safe. Whereas 24 respondents agreed that $100 \%$ complete, 26 respondents agreed $80 \%$ complete, 11 respondents agreed $70 \%$ complete, 8 respondents agreed $60 \%$ complete and only 6 respondents agreed $50 \%$ or less need to be completed. Whereas, Fig. 5 shows the slabs percentage of building safeness after completing the construction process. As showed below, 32 respondents said
$80 \%$ need to complete the roof of the building to be safe. Others, the 22 respondents agreed that $100 \%$ complete, 28 respondents agreed 90\% complete, 12 respondents agreed $70 \%$ complete, and 6 respondents agreed $60 \%$ need to be completed.

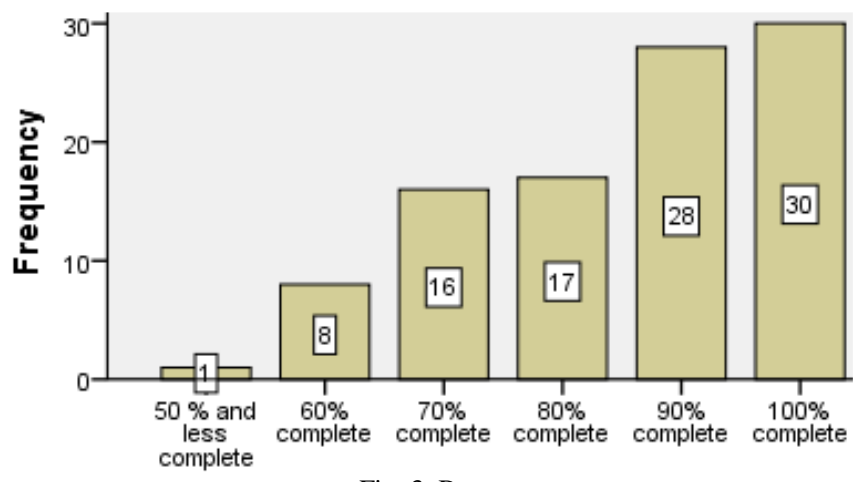

Fig. 3 Beam

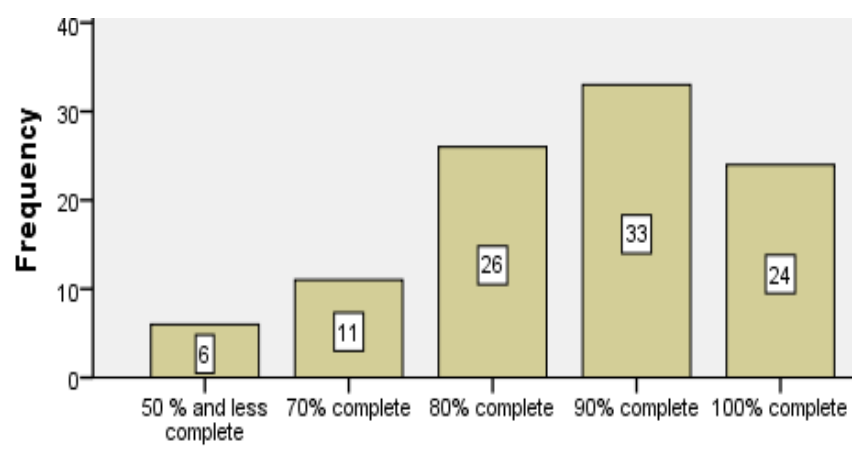

Fig. 4 Roof

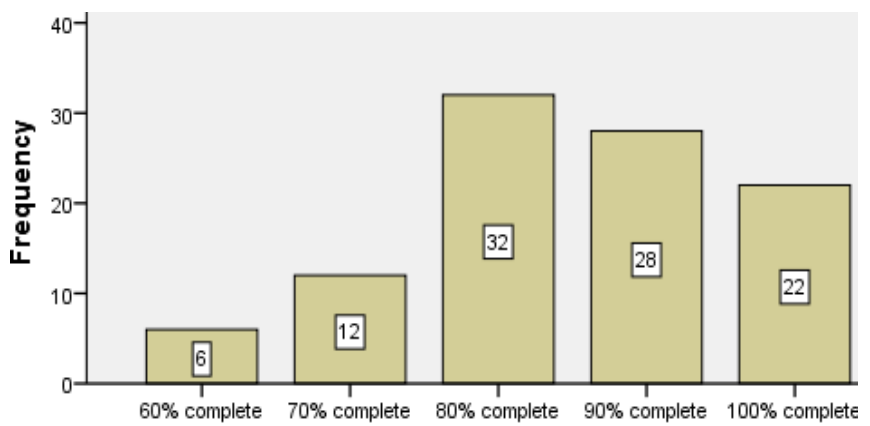

Fig. 5 Slabs

Fig. 6 shows the drainage percentage of building safeness after completing the construction process. As showed above, 32 respondents said $80 \%$ need to complete the drainage of the building to be safe. Others, the 22 respondents agreed that $100 \%$ complete, 28 respondents agreed $90 \%$ complete, 12 respondents agreed $70 \%$ complete, and 6 respondent agreed $60 \%$ need to be completed. Fig. 7 shows the ladder percentage of building safeness after completing the construction process. As showed below, 35 respondents said $80 \%$ need to complete the ladder of the building to be safe. Others, 27 respondents agreed that 100\% complete, 14 respondents agreed $90 \%$ complete, 18 respondents agreed $70 \%$ complete, 5 respondents agreed $60 \%$ complete, and only 1 respondent agree $50 \%$ or less need to be completed. 


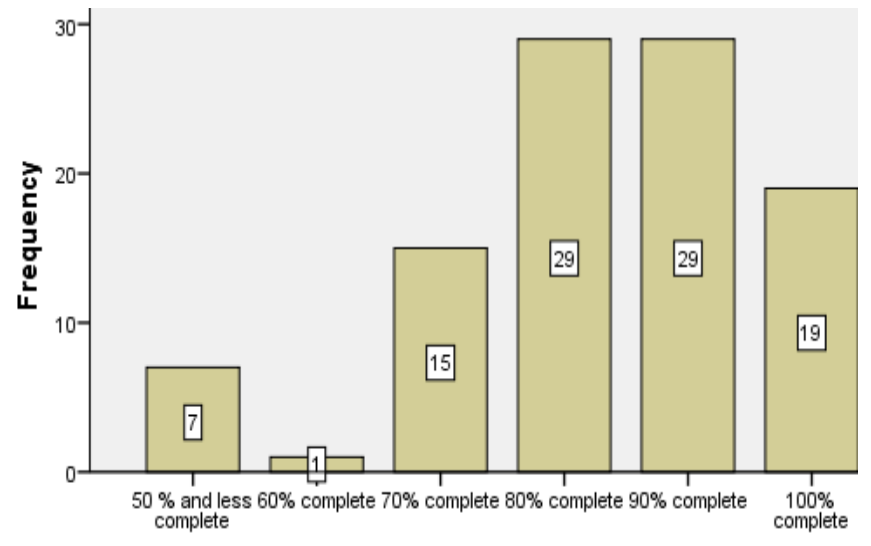

Fig. 6 Drainage

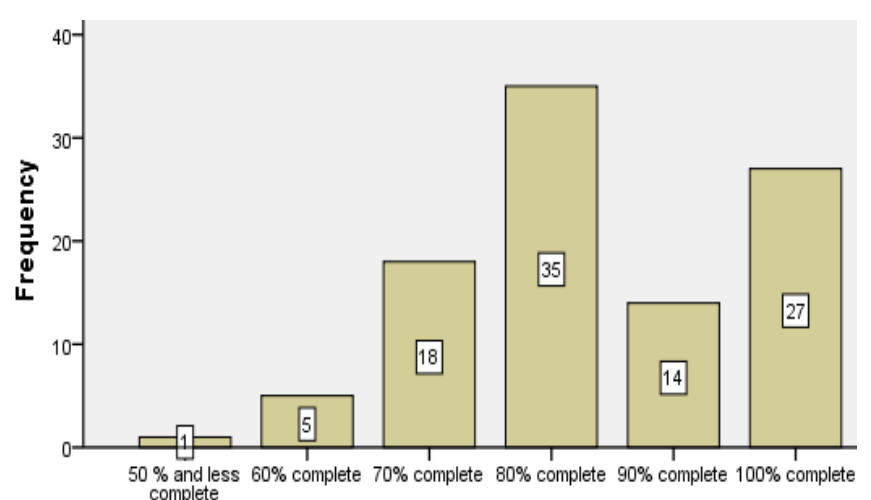

Fig. 7 Ladder

\section{B. Services Design}

Then, Fig. 8 until Fig. 13 show the results of distributed questionnaires for building safeness on design. Details on full explanations are discussed as follows.

Fig. 8 explains the electricity supply percentage of building safeness after completing the construction process. As can be seen, 34 respondents said $100 \%$ need to complete the electricity of the building to be safe. Whereas 28 respondents agreed that $90 \%$ complete, 27 respondents agreed $80 \%$ complete, 3 respondents agreed $70 \%$ complete, 4 respondents agreed $60 \%$ complete, and 4 respondents agreed $50 \%$ or less need to be completed. Whereas, Fig. 9 shows the lighting percentage of building safeness after completing the construction process. As can be seen, 27 respondents said $100 \%$ need to complete the lighting of the building to be safe. Whereas 23 respondents agreed that $90 \%$ complete, 25 respondents agreed $80 \%$ complete, 21 respondents agreed $70 \%$ complete, and 4 respondents agreed $60 \%$ need to be completed.

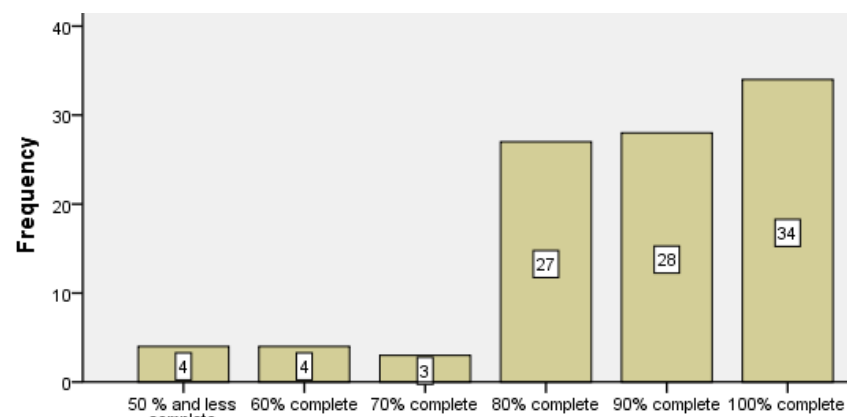

Fig. 8 Electricity supply

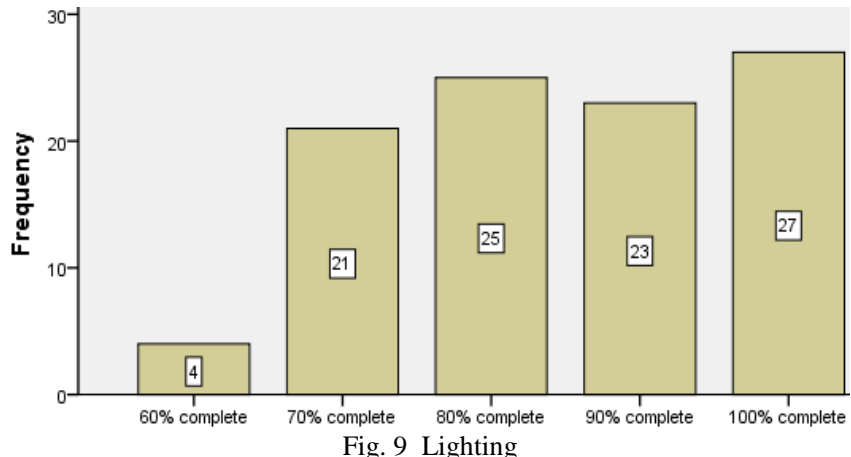

Fig. 10 discusses the ventilation percentage of building safeness after completing the construction process. As can be seen, 33 respondents said $80 \%$ need to complete the ventilation of the building to be safe. Whereas 24 respondents agreed that $100 \%$ complete, 13 respondents agreed $90 \%$ complete, 17 respondents agreed $70 \%$ complete, and 13 respondents agreed $60 \%$ need to be completed. Whereas, Fig. 11 shows the plumbing and sanitary service percentage of building safeness after complete the construction process. As can be seen, 29 respondents said $100 \%$ need to complete the plumbing and sanitary service of the building to be safe. Whereas 25 respondents agreed that $90 \%$ complete, 19 respondents agreed $80 \%$ complete, 20 respondents agreed $70 \%$ complete, 3 respondents agreed $60 \%$, and only 4 respondents agreed $50 \%$ or less need to be completed.
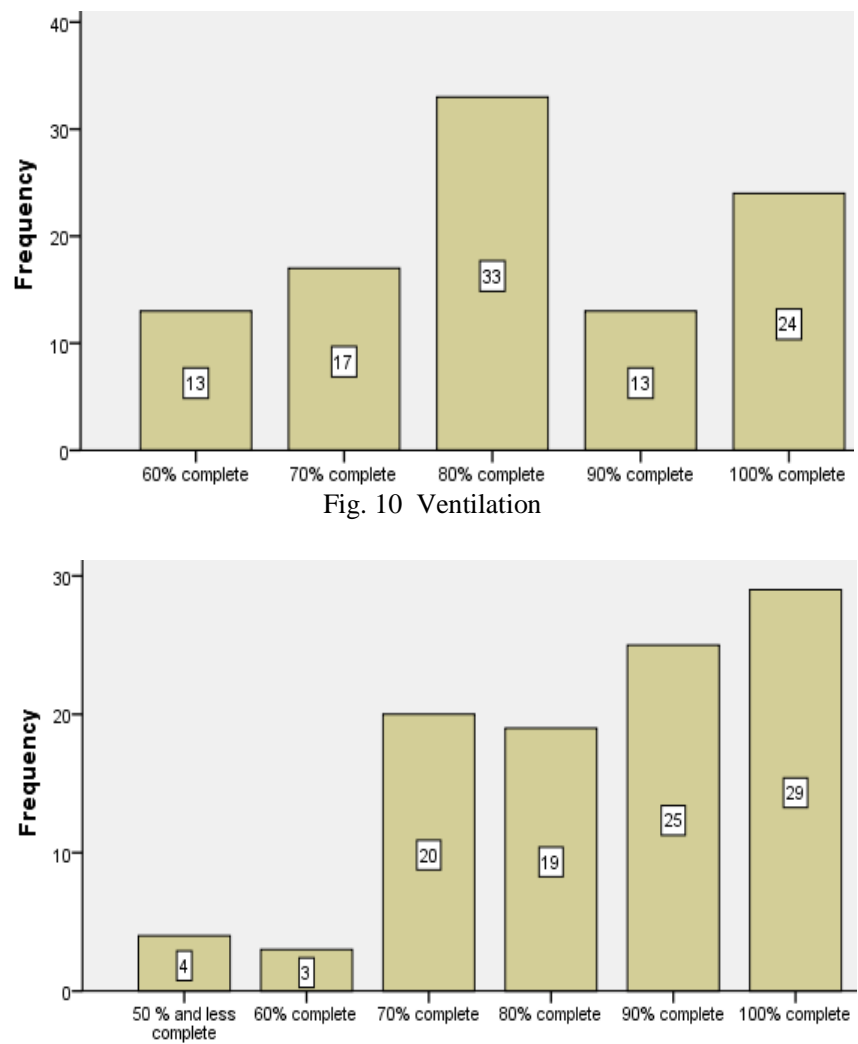

Fig. 11 Plumbing and sanitary service

Fig. 12 describes the fire services percentage of building safeness after completing the construction process. As can be seen, 39 respondents said $100 \%$ need to complete the fire services of the building to be safe. Whereas 27 respondents 
agreed that $90 \%$ complete, 20 respondents agreed $80 \%$ complete, 12 respondents agreed $70 \%$ complete and only 2 respondents agreed $50 \%$ or less need to be completed. Moreover, Fig. 13 describes the lifts percentage of building safeness after completing the construction process. As can be seen, 30 respondents said $100 \%$ need to complete the lifts of the building to be safe. Whereas 26 respondents agreed that 90\% complete, 24 respondents agreed $80 \%$ complete, 19 respondents agreed $70 \%$ complete, and only 1 respondent was agreed $50 \%$ or less need to be completed.

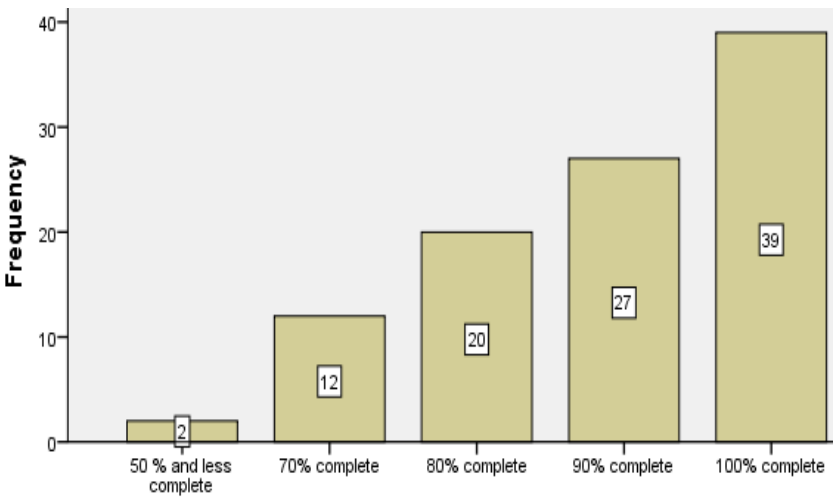

Fig. 12 Fire services

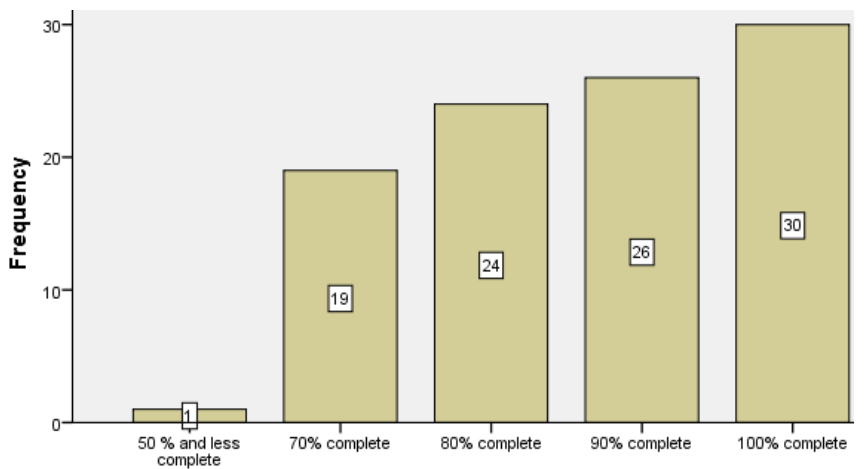

Fig. 13 Lifts

\section{Building Fitting}

Then, Fig. 14 until Fig. 18 explain the results of distributed questionnaires for building safeness on building fitting. Details on full explanations are discussed as follows.

Fig. 14 explains the emergency door percentage of building safeness after completing the construction process. As can be seen, 46 respondents said $90 \%$ need to complete the emergency door of the building to be safe. Whereas 32 respondents agreed that $100 \%$ complete, 7 respondents agreed $80 \%$ complete, 11 respondents agreed $70 \%$ complete, and only 4 respondents agreed $60 \%$ need to be completed. Moreover, Fig. 15 discusses the foyer area percentage of building safeness after completing the construction process. As can be seen, 39 respondents said $100 \%$ need to complete the foyers area of the building to be safe. Whereas 21 respondents agreed that $90 \%$ complete, 19 respondents agreed $80 \%$ complete, 18 respondents agreed $70 \%$ complete, and only 3 respondents agreed $60 \%$ need to be completed.

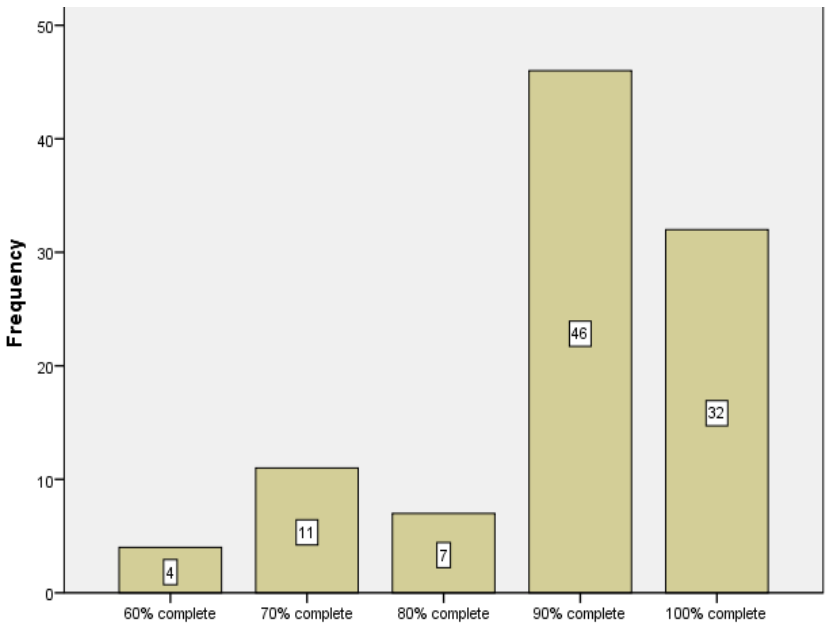

Fig. 14 Emergency door

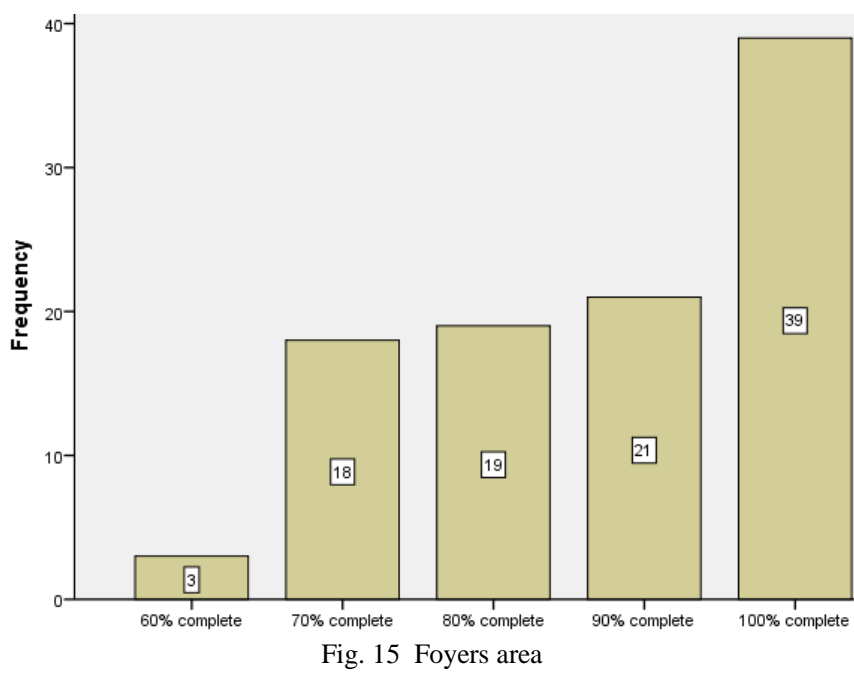

Fig. 16 describes the utility area percentage of building safeness after completing the construction process. As can be seen, 33 respondents said $80 \%$ need to complete the utility area of the building to be safe. Whereas the 15 respondents agreed that $100 \%$ complete, 28 respondents agreed $90 \%$ complete, 17 respondents agreed $70 \%$ complete and only 7 respondents agreed $60 \%$ need to be completed. Moreover, Fig. 17 describes the water fountain percentage of building safeness after completing the construction process. As can be seen, 36 respondents said $100 \%$ need to completed the water fountain of the building to be safe. Whereas 15 respondents agreed that $90 \%$ complete, 16 respondents agreed $80 \%$ complete, 18 respondents agreed $70 \%$ complete, 13 respondent were agreed $60 \%$ complete, and only 2 respondents agreed $50 \%$ or less need to be completed. Furthermore, the Fig. 18 shows the emergency generator percentage of building safeness after completing the construction process. As can be seen, 35 respondents said $100 \%$ need to complete the emergency generator of the building to be safe. Whereas 16 respondents agreed that $90 \%$ complete, 32 respondents agreed $80 \%$ complete, 13 respondents agreed $70 \%$ complete and only 4 respondents agreed $50 \%$ or less need to be completed. 


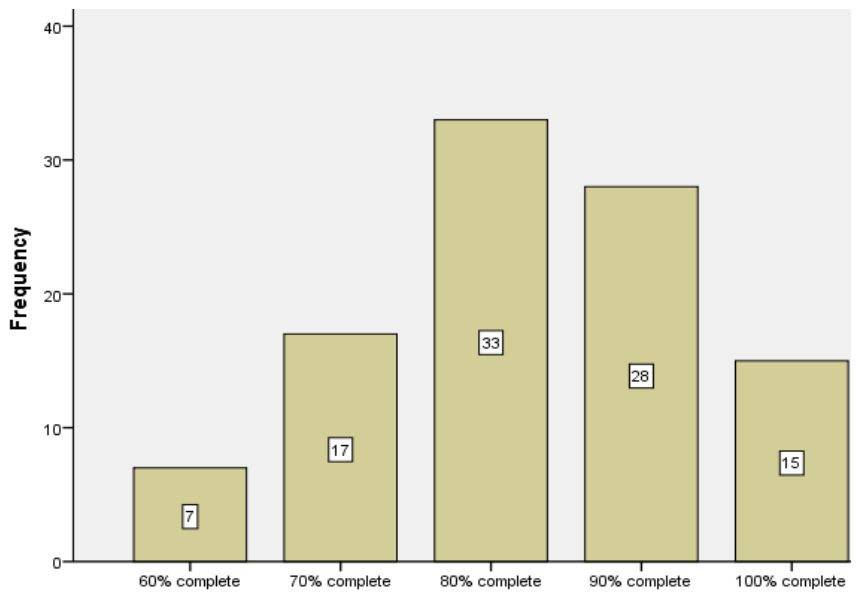

Fig. 16 Utility area

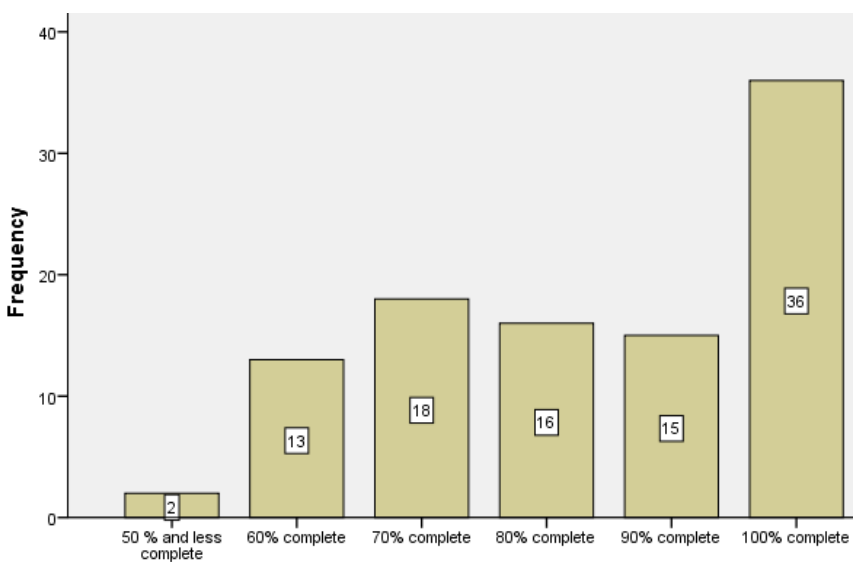

Fig. 17 Water fountain

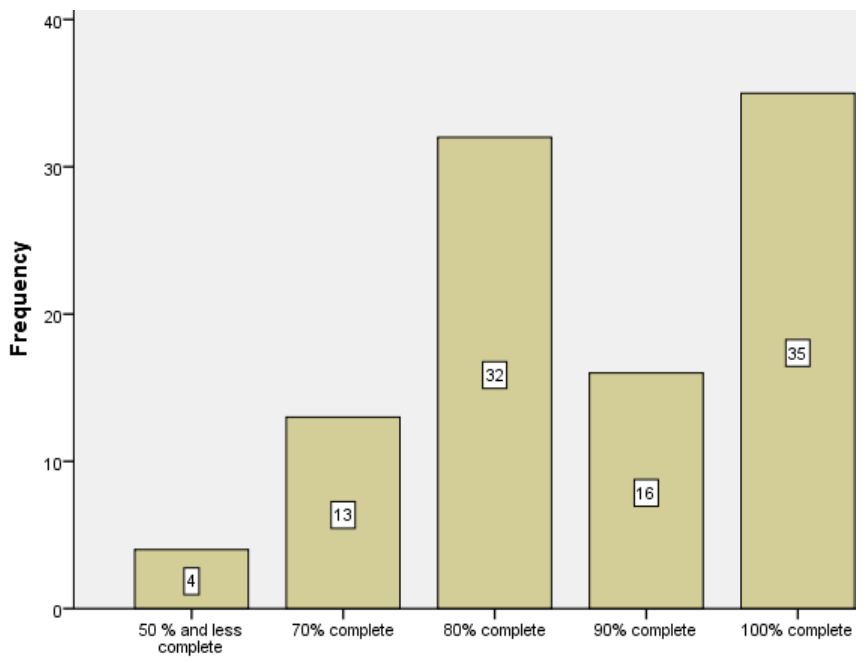

Fig. 18 Emergency generator

\section{Structure of Building}

Next, Fig. 19 until Fig. 22 explain the results of distributed questionnaires for building safeness towards disasters' environment. Details on full explanations are discussed as follows.

Fig. 19 explains the flood percentage of building safeness after completing the construction process. As can be seen, 44 respondents said $90 \%$ need to completed as building to be safe. Whereas 26 respondents agreed that $100 \%$ complete, 16 respondents agreed $80 \%$ complete, 8 respondents agreed $70 \%$ complete, 2 respondents agreed $60 \%$ complete, and only 4 respondents agreed $50 \%$ and less need to be completed. Moreover, Fig. 20 explains the earthquake percentage of building safeness after completing the construction process. As can be seen, 41 respondents said $50 \%$ and less in prepare the earthquake of the building to be safe. Whereas 28 respondents agreed that $60 \%$ complete, 17 respondents agreed $70 \%$ complete, 9 respondents agreed $80 \%$ complete, 1 respondent was agreed $90 \%$ complete, and only 4 respondents agreed $100 \%$ need to be completed.

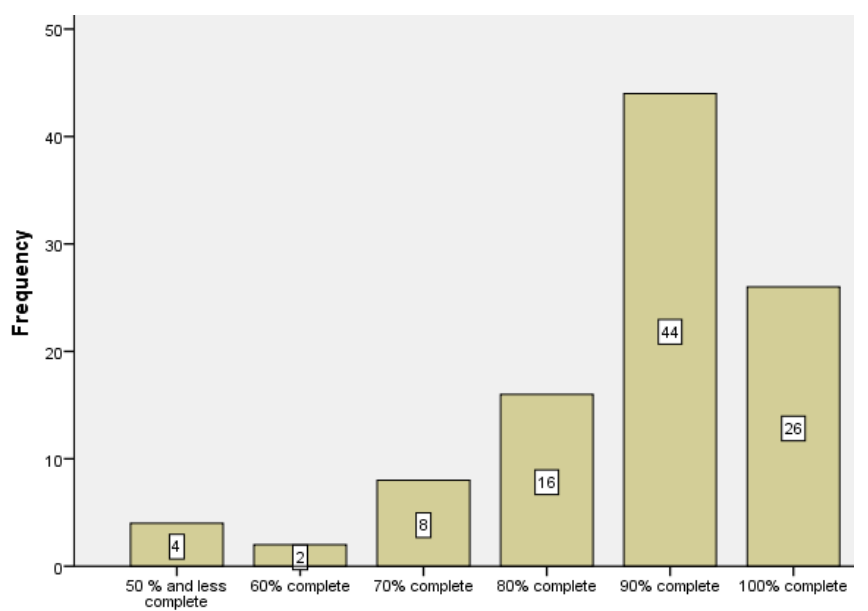

Fig. 19 Flood

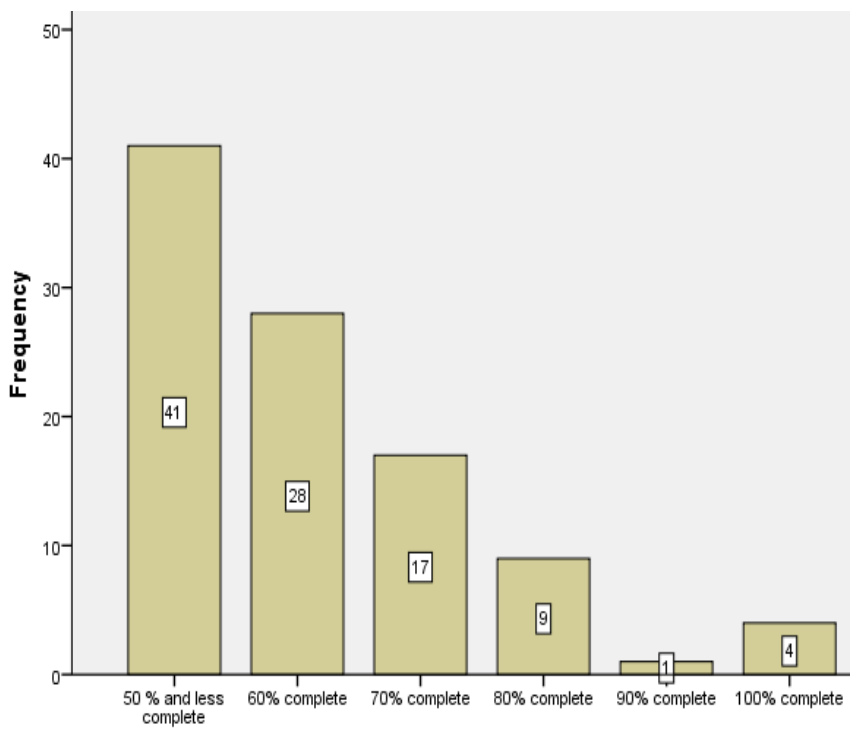

Fig. 20 Earthquake

Fig. 21 describes the fire percentage of building safeness after completing the construction process. As can be seen, 32 respondents said $90 \%$ need to completed as building to be safe. Whereas 21 respondents agreed that $100 \%$ complete, 21 respondents agreed $80 \%$ complete, 12 respondents agreed $70 \%$ complete, 5 respondents agreed $60 \%$ complete, and 9 respondents agreed $50 \%$ and less need to be completed.

Moreover, Fig. 22 describes the typhoon percentage of building safeness after completing the construction process. As can be seen, 22 respondents said $80 \%$ in prepare the typhoon of the building to be safe. Whereas 20 respondents agreed that $100 \%$ complete, 9 respondents agreed $90 \%$ complete, 15 respondents agreed $70 \%$ complete, 16 
respondents agreed $60 \%$ complete, and 18 respondents agreed $50 \%$ and less need to be completed.

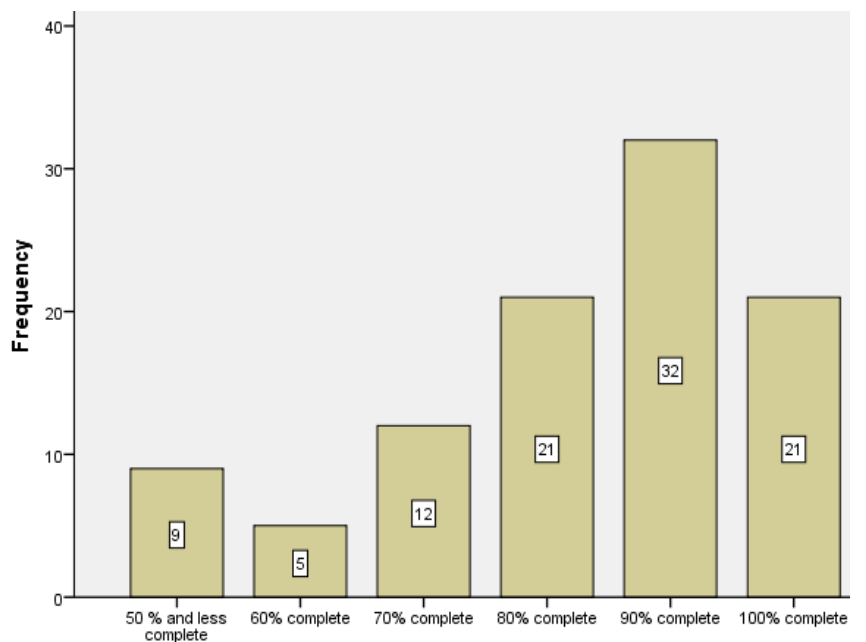

Fig. 21 Fire

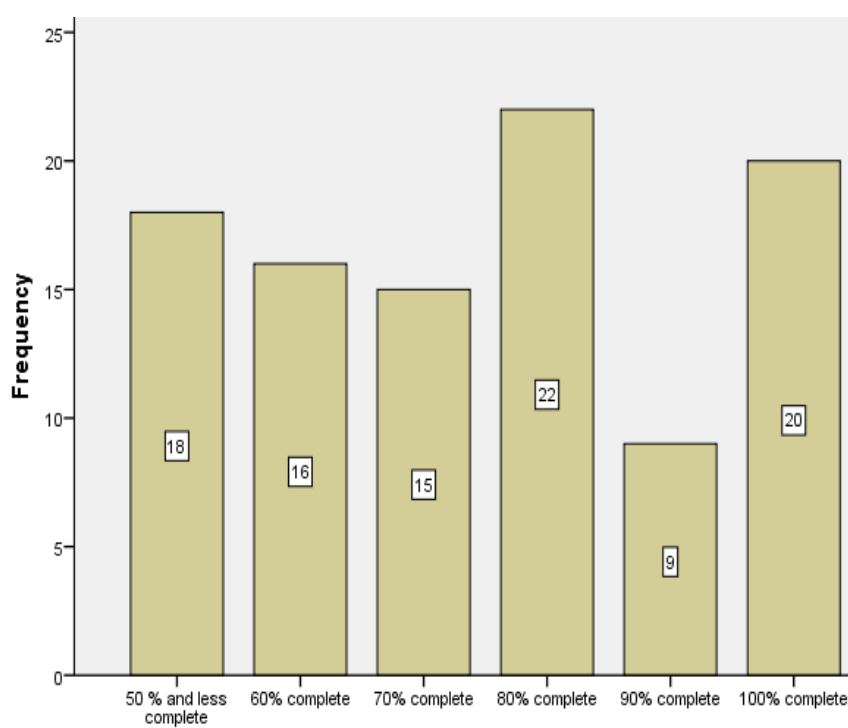

Fig. 22 Typhoon

\section{E. Management}

Lastly, Fig. 23 until Fig. 25 discussed the results of distributed questionnaires for building safeness towards security management. Details on full explanations are discussed as follows.

Fig. 23 discussed the security management percentage of building safeness after completing the construction process. As can be seen, 40 respondents said $90 \%$ need to complete the security management of the building to be safe. Whereas 22 respondents agreed that $100 \%$ complete, 21 respondent were agreed $80 \%$ complete, 11 respondents agreed $70 \%$ complete, 3 respondents agreed $60 \%$ complete, and only 3 respondents agreed $50 \%$ and less need to be completed. Moreover, Fig. 24 discussed the emergency evacuation plan percentage of building safeness after completing the construction process. As can be seen, 29 respondents said $90 \%$ need to complete the emergency evacuation plan of the building to be safe. Whereas 23 respondents agreed that $100 \%$ complete, 17 respondents agreed $80 \%$ complete, 15 respondents agreed $70 \%$ complete, 14 respondents agreed
$60 \%$ complete, and only 2 respondents agreed $50 \%$ and less need to be completed.

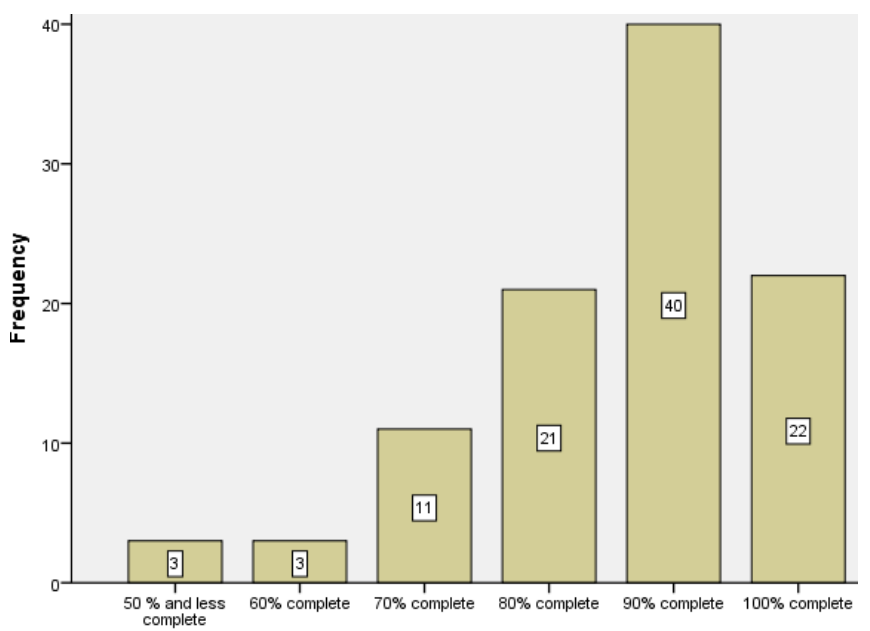

Fig. 23 Security management

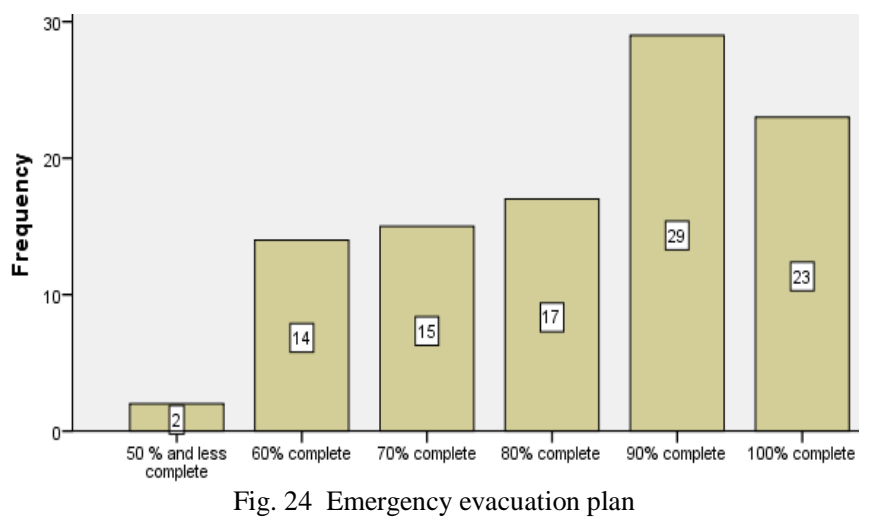

Fig. 25 discussed the documentation and evaluation percentage of building safeness after completing the construction process. As can be seen, 27 respondents said $80 \%$ need to complete the documentation and evaluation of the building to be safe. Whereas 14 respondents agreed that $100 \%$ complete, 18 respondents agreed $90 \%$ complete, 15 respondents agreed $70 \%$ complete, 21 respondents agreed $60 \%$ complete, and only 5 respondents agreed $50 \%$ and less need to be completed.

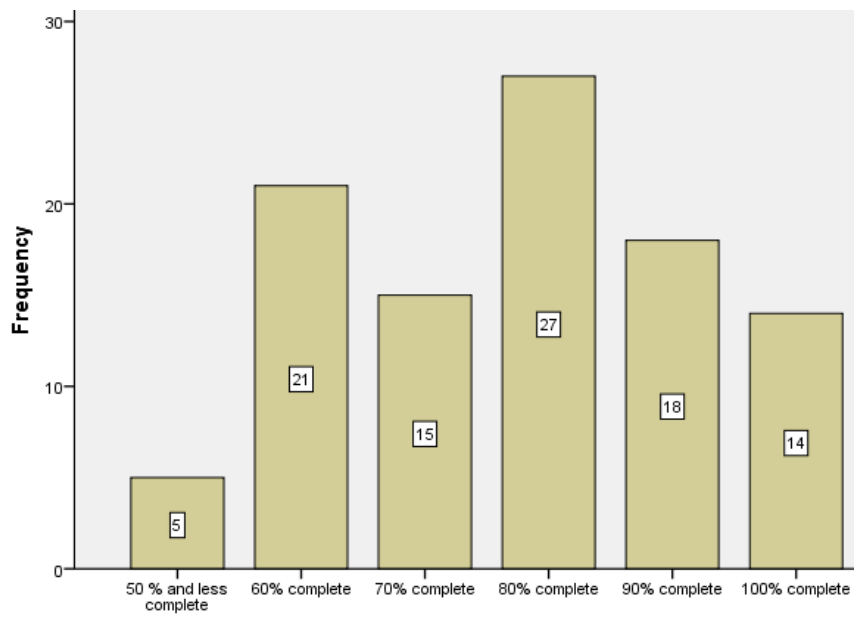

Fig. 25 Documentation and evaluation 
Fig. 26 shows the safety education percentage of building safeness after completing the construction process. As can be seen, 36 respondent said $70 \%$ need to complete the safety education of the building to be safe. Whereas 8 respondents agreed that $100 \%$ complete, 7 respondents agreed 90\% complete, 29 respondent were agree $80 \%$ complete, 16 respondents agreed $60 \%$ complete, and only 4 respondents agreed $50 \%$ and less need to be completed.

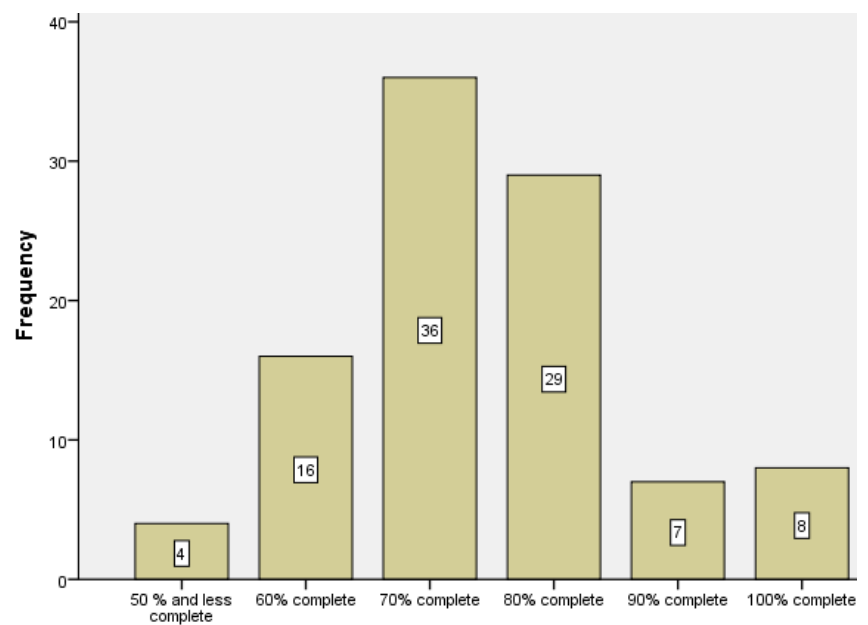

Fig. 26 Safety education

Fig. 27 shows the occupant safety education percentage of building safeness after completing the construction process. As can be seen, 42 respondents said $80 \%$ need to completed the occupant safety education of the building to be safe. Whereas 6 respondents agreed that $100 \%$ complete, 31 respondents agreed 90\% complete, 14 respondents agreed $70 \%$ complete, 3 respondents agreed $60 \%$ complete, and only 4 respondents agreed $50 \%$ and less need to be completed.

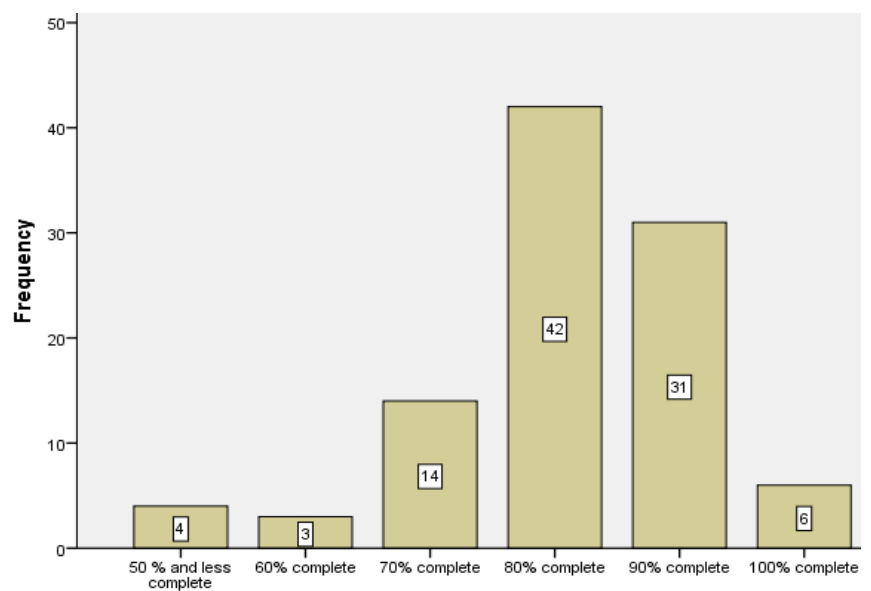

Fig. 27 Occupant safety education

Fig. 28 explains the waste and cleaning service percentage of building safeness after completing the construction process. As can be seen, 32 respondents said $90 \%$ need to completed the waste and cleaning service of the building to be safe. Whereas 26 respondents agreed that $100 \%$ complete, 7 respondents agreed $80 \%$ complete, 22 respondents agreed $70 \%$ complete, 10 respondents agreed $60 \%$ complete, and only 3 respondents agreed $50 \%$ and less need to be completed.

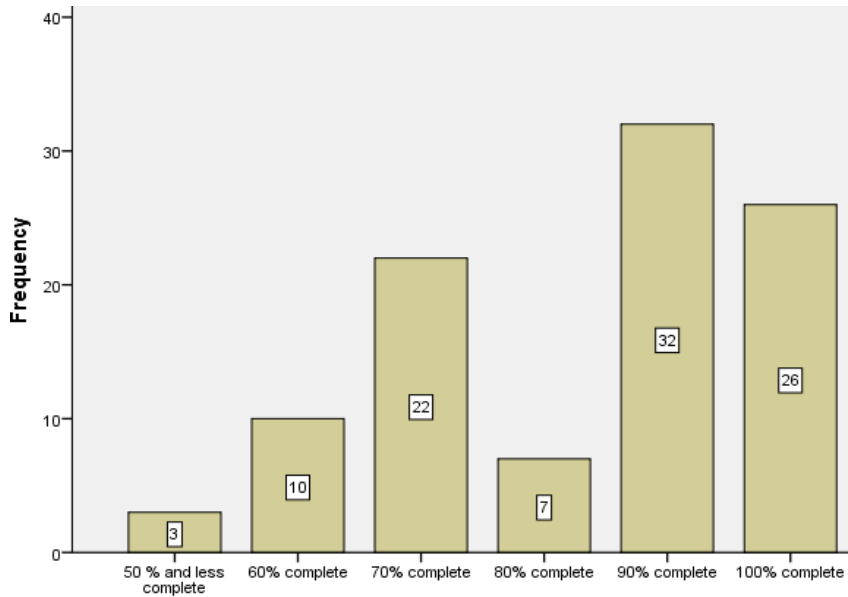

Fig. 28 Waste and cleaning services

\section{F. Structural Equation Modelling}

After completing the survey on building safeness towards all subcriteria on building design and management, then this section discusses on efficiency for all subcriteria using correlation, SEM, CMIN, GFI, NF, IFI, TFI, CFI, AIC, and RMSEA.

Table 4 discusses on the correlation between all subcriteria. A correlation of -1 indicates the negative correlation where +1 indicates the positive correlation. There are nine correlations between subcriteria that are a moderate correlation. It is between slabs and beam which is $0.560^{* *}$, ventilation and slabs which is $0.549^{* *}$, ventilation and electricity supply which is $0.516^{* *}$, utility and drainage which is $0.528^{* *}$, emergency generator and emergency door which is 0.522 , emergency generator and utility area which is 0.589 , flood and slabs which is $0.502 * *$, security management and slabs which is $0.500 * *$. It is found that this subcriteria have moderate correlation relationship between the subcriteria. The other correlations of the subcriteria also can be seen in Table 4 .

Using the efficiency stated in Table 4, this study developed the proposed model of SEM for all subcriteria as follows.

Based on Fig. 29 the modification index (MI) provided by statistical software (AMOS 18.0) indicates that error covariance should be added are foyers area-water fountain, water fountain-ventilation, water fountain-roof, documentation and evaluation-safety education, emergency evacuation plan-flood, roof-fire, fire-lifts, plumbingstructure, roof-beam, drainage-beam, drainage-roof. The model was modified according to MI, as model 2 (Fig. 30). The Chi-Square value was reduced from model 1 to model 2 as Fig. 30, 637.877 to 453.656 and CMIN value was reduced from 2.161 to 1.609 , GFI value index increased from 0.694 to 0.768 , NFI increased from 0.490 to 0.638 , IFI value increased from 0.642 to 0.823 , TLI value increased from 0.592 to 0.787 , CFI value increased from 0.630 to 0.815 , AIC value decreased from 749.877 to 591.656 and RMSEA value decreased from 0.108 to 0.078 . 
TABLE IVV

ESTIMATES OF STANDARD REGRESSION WEIGHT BY SEM

\begin{tabular}{|c|c|}
\hline Variables & Standard Regression Weight $(\beta)$ \\
\hline \multicolumn{2}{|l|}{ Services } \\
\hline Electricity Supply & $0.653 * * *$ \\
\hline Lighting & $0.679 * * *$ \\
\hline Ventilation & $0.720 * * *$ \\
\hline Plumbing and Sanitary Services & 0.747 \\
\hline Fire Services & $0.523 * * *$ \\
\hline Lifts & $0.513 * * *$ \\
\hline \multicolumn{2}{|l|}{ Structures } \\
\hline Beam & $0.654 * * *$ \\
\hline Roof & $0.610 * * *$ \\
\hline Slabs & $0.755 * * *$ \\
\hline Drainage & $0.646 * * *$ \\
\hline Ladder & 0.602 \\
\hline \multicolumn{2}{|l|}{ Building Fitting } \\
\hline Emergency Door & $0.551 * * *$ \\
\hline Foyers Area & $0.626 * * *$ \\
\hline Water Fountain & $0.594 * * *$ \\
\hline Utility Area & $0.763 * * *$ \\
\hline Emergency Generator & 0.755 \\
\hline \multicolumn{2}{|l|}{ Weather } \\
\hline Flood & $0.720 * * *$ \\
\hline Earthquake & 0.153 \\
\hline Fire & $0.669 * * *$ \\
\hline Typhoon & 0.571 \\
\hline \multicolumn{2}{|l|}{ Management } \\
\hline Security Management & $0.698 * * *$ \\
\hline Emergency Evacuation Plan & $0.629 * * *$ \\
\hline Documentation and Evaluation & $0.261 *$ \\
\hline Safety Education & 0.077 \\
\hline Occupant Safety Management & $0.452 * * *$ \\
\hline Waste and Cleaning Services & 0.652 \\
\hline Services <--- Structure & $0.863 * * *$ \\
\hline Structure <--- Building Fitting & $0.468 *$ \\
\hline Structure <--- Weather & $0.478 *$ \\
\hline Building Fitting <--- Management & $0.747 * * *$ \\
\hline
\end{tabular}

Note: Significant levels: $* * * p<0.001,{ }^{* *} \mathrm{p}<0.01,{ }^{*} \mathrm{p}<0.05$

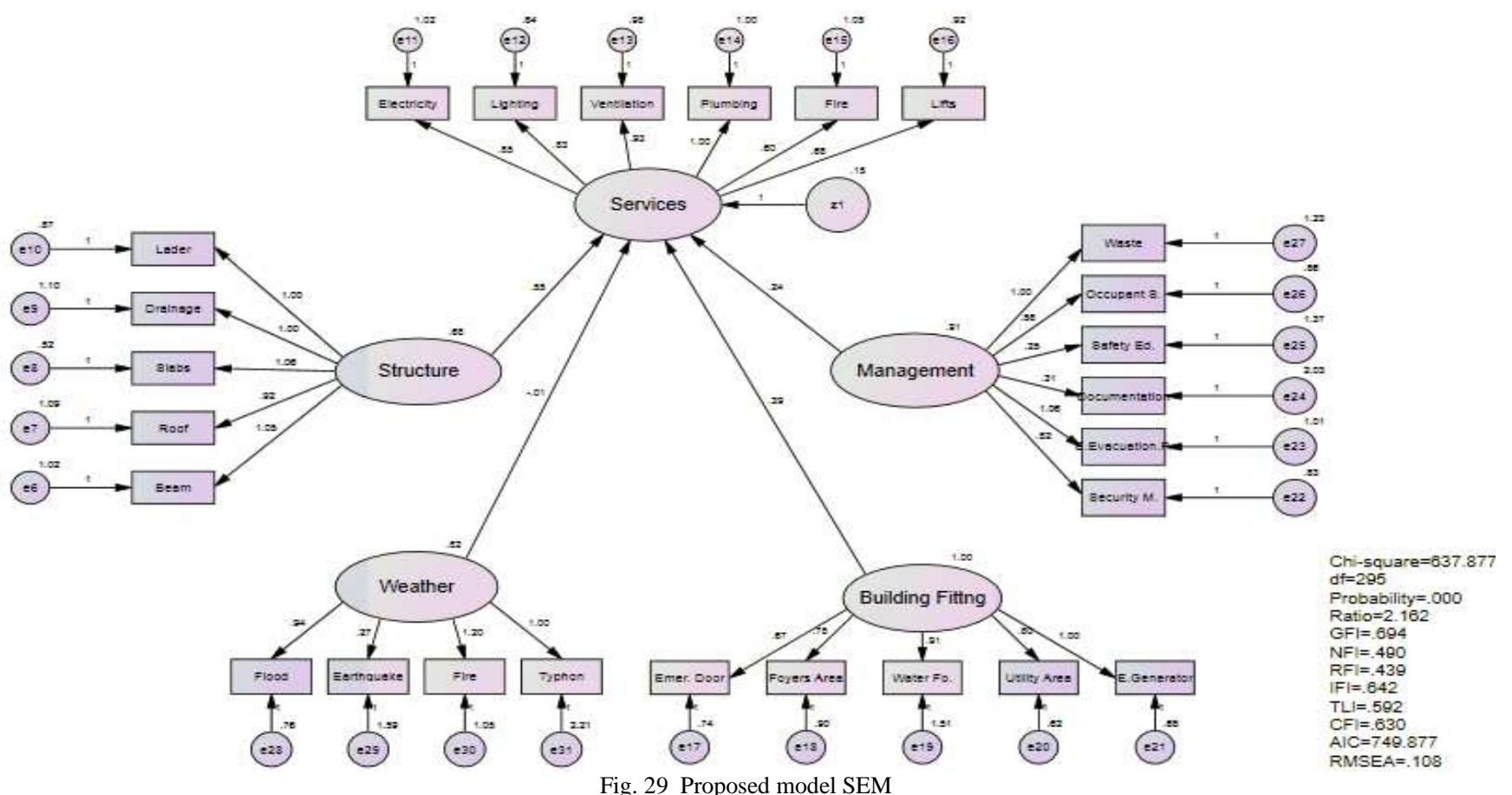

Fig. 29 Proposed model SEM 


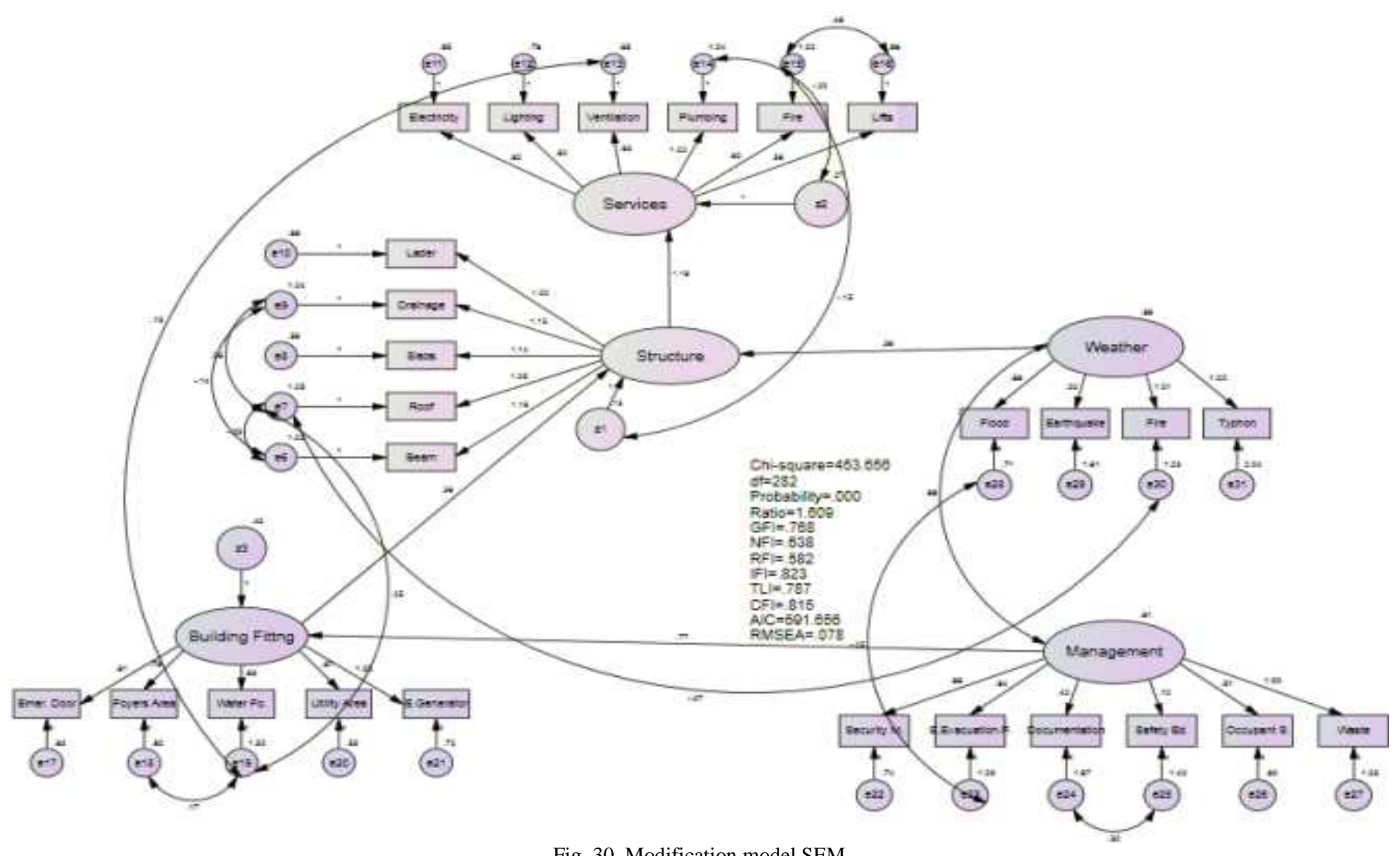

Fig. 30 Modification model SEM

Based on Fig. 30, it is seen that the entire model shows a good fit although some of the criteria were not followed as required. The CMIN value in this model was 1.609 . The modification model shows the CMIN value of 3 or less is acceptable, and the model is assumed to be a good fit with the observed data. The RMSEA value in this model was 0.0787 . The range value for RMSEA indicated as the value 0 interpreted as an exact fit, values less than 0.05 are a close fit, where value between $0.05-0.08$ are a fair fit, values between 0.08 and 0.10 are mediocre fit and the values more than 0.10 are presented as a poor fit. Moreover, the modification model shows the value of GFI, NFI, IFI, TLI and CFI lesser than 0.90 as showed in the Fig. 30. Based on the results from CMIN and RMSEA value, the model shown is a fair fit model.

Based on all results, it was found that five main subcriteria services were statistically significant as seen in Table 4 . The electricity supply $(\beta=0.653, p<0.001)$, lighting $(\beta=0.679, \mathrm{p}<0.001)$, ventilation $(\beta=0.720, \mathrm{p}<$ $0.001)$, fire services $(\beta=0.523, \mathrm{p}<0.001)$ and lifts $(\beta=$ $0.513, \mathrm{p}<0.001)$ were statistically significant. Wherelse, the plumbing and sanitary services were slightly unsignificant. Moreover, the structure observation for four main subcriteria were statistically significant which are beam $(\beta=0.654, \mathrm{p}<$ $0.001)$, roof $(\beta=0.610, \mathrm{p}<0.001)$, slabs $(\beta=0.755, \mathrm{p}<$ $0.001)$ and drainage $(\beta=0.523, \mathrm{p}<0.001)$. Present study also shows that the emergency door $(\beta=0.551, \mathrm{p}<0.001)$, foyers area $(\beta=0.626, p<0.001)$, water fountain $(\beta=0.594$, $\mathrm{p}<0.001)$ and utility area $(\beta=0.763, \mathrm{p}<0.001)$ were also statistically significant. Then, for weather only two of the subcriteria were statistically significant which are flood $(\beta=$
$0.720, \mathrm{p}<0.001)$ and fire $(\beta=0.669, \mathrm{p}<0.001)$, the rests are slightly insignificant. Then, the earthquake and typhoon subcriteria also shown slightly insignificant. The management observation also shows 4 subcriteria statistically significant which are security management $(\beta=$ $0.698, \mathrm{p}<0.001)$, emergency evacuation plan $(\beta=0.629, \mathrm{p}$ $<0.001)$, documentation and evaluation $(\beta=0.720, \mathrm{p}<0.05)$ and occupant safety management $(\beta=0.452, \mathrm{p}<0.001)$. The slighlty insignificant is maybe due to the limited questionnaire survey.

\section{IV.CONCLUSION}

In this paper, we have presented a survey on building safety using a statistical approach. The safety of the building is focused on two major parts which are the building design and building management. The building designs are divided into building structure [23], service design, building fitting and hazard environment. Whereas, building management focus on management. 100 questionnaire surveys were distributed among selected engineers, contractors and public throughout Malaysia. The survey on the building safety after completing the construction process is successfully discussed. The results are analysed using a statistical approach. In light of the results, it can be concluded that the proposed method is able to reach the optimum concerned in maintaining the safety of the building after completing the construction process. This is just the beginning of surveying the building safety, thus for our future work, we aim to apply other mathematical methods in solving the problems on constructions. 


\section{REFERENCES}

[1] J. K. Yates and E. E. Lockley, "Documenting and analyzing construction failure," Journal of Construction Engineering and Management, vol. 128, pp. 8-17, Feb. 2002.

[2] K. Wardhana and F. C. Hadipriono, "Study of recent building failures in the United States," Journal of Performance of Constructed Facilities, vol. 17, pp. 151-158, Aug. 2003.

[3] K. Mora, J. Chang, A. Beatson, and C. Morahan, "Public perceptions of building seismic safety following the Canterbury earthquakes: A qualitative analysis using Twitter and focus groups," International Journal of Disaster Risk Reduction, vol. 13, pp. 1-9, Sep. 2015.

[4] S. Murtiadi, "Review of Indonesian standard for concrete building subjected to fire," Procedia Engineering, vol. 54, pp. 668-674, Dec. 2013

[5] M. A. Aly "Pressure integration technique for predicting windinduced response in high-rise buildings," Alexandria Engineering Journal, vol. 52, pp. 717-731, Dec. 2013.

[6] N. Khalil and A. H. Nawawi, "Performance analysis of government and public buildings via post occupancy evaluation," Asian Social Science, vol. 4, pp. 103-112, Feb. 2008.

[7] A. O. Michael and A. R. Razak, "The study of claims arising from building collapses: case studies from Malaysia, Nigeria, Singapore and Thailand," Civil and Environmental Research, vol. 3, pp. 113129, 2013.

[8] A. Ramli, Z. A. Akasah, and M. I. M. Masirin, "Safety and health factors influencing performance of Malaysian low-cost housing: Structural Equation Modeling (SEM) approach," Procedia-Social and Behavioral Sciences, vol. 129, pp. 475-482, May 2014.

[9] K. J. Trilok and S. Amitha, "Service quality model: Model fit indices results," International Journal of Engineering Research and Technology, vol. 1, pp. 1-12, Dec. 2012.

[10] A. Aziz, M. M. S. Ahmad, M. M. Shaladdin, A. Norsiah, and I. Yahaya, "Modeling quality of life and life satisfaction amongst homestay program participants in Malaysia," International Journal of Social Sciences, vol. 7, pp. 194-204, Jan. 2013.

[11] F. Chan, K. Lee, E. Lee, and C. A. Allen, "Structural equation modeling in rehabilitation counseling research," Rehabilitation Counseling Bulletin, vol. 54, pp. 53-66, Oct. 2007.

[12] J. L. Perry, A. R. Nicholls, P. J. Clough, and L. Crust, "Assessing model fit: Caveats and recommendations for confirmatory factor analysis and exploratory structural equation modelling," Measurement in Physical Education and Exercise Science, vol. 19, pp. 12-21, Jan. 2015.
[13] M. I. M. Shafiq, W. A. W. M. Amir, and A. H. N. Fadhlina, "Comparative comprehensive statistical modeling in different stage of blood pressure based on high density lipoprotein cholesterol level," International Journal of Advances in Computer Science and Technology, vol. 2, pp. 223-229, 2013.

[14] S. K. Wong, A. K. C. Cheung, Y. Yau, D. C. W. Ho, and K. W. Chau, "Are our residential buildings healthy and safe? A survey in Hong Kong,” Structural Survey, vol. 24, pp. 77-86, Jan. 2006.

[15] J. H. K. Lai and F. W. H. Yik, "Law and building services maintenance in Hong Kong," HKIE Transactions, vol. 11, pp. 7-14, 2004.

[16] K. M. Pollack, M. M. Bailey, A. C. Gielen, S. Wolf, M. E. Auld, D. A. Sleet, and K. K. Lee, "Building safety into active living initiatives," Preventive Medicine, vol. 69, pp. S102-S105, Dec. 2014.

[17] M. Kobes, I. Helsloot, B. D. Vries, and J. G. Post, "Building safety and human behaviour in fire: A literature review," Fire Safety Journal, vol. 45, pp. 1-11, Jan. 2010.

[18] B. J. Meacham, D. Charters, P. Johnson, and M. Salisbury, Building Fire Risk Analysis, ser. SFPE Handbook of Fire Protection Engineering. New York, USA: Springer, 2016.

[19] S. H. Wang, W. C. Wang, K. C. Wang, and S. Y. Shih, "Applying building information modelling to support fire safety management," Automation in Construction, vol. 59, pp. 158-167, Nov. 2015.

[20] S. Ainuddin, U. Mukhtar, and S. Ainuddin, "Public perception about enforcement of building codes as risk reduction strategy for seismic safety in Quetta, Baluchistan," International Journal of Disaster Risk Reduction, vol. 9, pp. 99-106, Sep. 2014.

[21] A. Ganah and G. John, "Integrating building information modeling and health and safety for onsite construction," Safety and Health Work, vol. 6, pp. 39-45, Mar. 2015.

[22] L. Cronbach, "Coefficient alpha and the internal structure of tests," Psychomerika, vol. 16, pp. 297-334, Sep. 1951.

[23] I. M. Yassin, A. Zabidi, M. S. A. M. Ali, N. M. Tahir, H. A. Hassan, H. Z. Abidin, and Z. I. Rizman, "Binary particle swarm optimization structure selection of nonlinear autoregressive moving average with exogenous inputs (NARMAX) model of a flexible robot arm," International Journal on Advanced Science, Engineering and Information Technology, vol. 6, pp. 630-637, Oct. 2016.

[24] M. N. M. Nor, R. Jailani, N. M. Tahir, I. M. Yassin, Z. I. Rizman, and R. Hidayat, "EMG signals analysis of BF and RF muscles in autism spectrum disorder (ASD) during walking," International Journal on Advanced Science, Engineering and Information Technology, vol. 6, pp. 793-798, Oct. 2016. 